\title{
PENGARUH HARGA DAN KUALITAS LAYANAN TERHADAP KEPUASAN DAN LOYALITAS NASABAH PADA BANK SINARMAS KK DURI PULO GAMBIR JAKARTA PUSAT
}

\author{
Burhanudin \\ Program Studi Bimbingan dan Konseling, FIPPS, \\ Universitas Indraprasta PGRI \\ Jl. Nangka No. 58 C Tanjung Barat, Jagakarsa, Jakarta Selatan \\ email : hanzqinthar@gmail.com \\ Diterima: Maret 2018; Disetujui: Maret 2018; dipublikasikan: April 2018
}

\begin{abstract}
ABSTRAK
Tujuan penelitian ini adalah untuk mengetahui dan menganalisis pengaruh harga dan kualitas layanan terhadap kepuasan dan loyalitas nasabah Bank Sinarmas KK Duri Pulo Gambir Jakarta Pusat. Sampel dari penelitian ini adalah 94 nasabah Bank Sinarmas KK Duri Pulo Gambir Jakarta Pusat. Hasil penelitian menunjukkan bahwa terdapat pengaruh yang signifikan antara : (1) harga terhadap kepuasan nasabah, (2) kualitas layanan terhadap kepuasan nasabah, (3) harga terhadap loyalitas nasabah, (4) kualitas layanan terhadap loyalitas nasabah, (5) dan kepuasan nasabah terhadap loyalitas nasabah. Secara keseluruhan, baik secara langsung maupun tidak langsung besarnya pengaruh diketahui $34,62 \%$, sedangkan sisanya sebesar $65,38 \%$ dipengaruhi oleh faktor lain yang tidak diteliti dalam penelitian ini.
\end{abstract}

Kata kunci : Loyalitas Nasabah, Kepuasan Nasabah, Kualitas Layanan dan Harga

\begin{abstract}
The purpose of this research is to know and analyze the influence of price and quality of service to customer satisfaction and loyalty of Bank Sinarmas KK Duri Pulo Gambir Central Jakarta. The sample of this research is 94 customers of Bank Sinarmas KK Duri Pulo Gambir Central Jakarta. The result of research indicates that there are significant influence between: (1) price to customer satisfaction, (2) quality of service to customer satisfaction, (3) price to customer loyalty, (4) quality of service to customer loyalty, (5) and customer satisfaction to customer loyalty. Overall, either directly or indirectly the magnitude of the influence is known $34.62 \%$, while the rest of $65.38 \%$ influenced by other factors not examined in this study.
\end{abstract}

Keywords: Customer Loyalty, Customer Satisfaction, Service Quality and Price 


\section{PENDAHULUAN}

Pada situasi persaingan perbankan, bank-bank membutuhkan usaha yang keras untuk mendapat calon nasabah dan mempertahankan yang sudah ada di tangan. Keberhasilan usaha tersebut sangat ditentukan oleh kemampuan perusahaan dalam memberikan pelayanan yang berkualitas. Kualitas pelayanan tercermin dari kepuasan nasabah untuk melakukan penggunaan ulang jasa perbankan. Kepuasan nasabah dalam menggunakan jasa atau produk yang ditawarkan dapat dijadikan masukan bagi pihak manajemen untuk meningkatkan dan memperbaiki kualitas pelayanan yang diberikan. Untuk itu karyawan bagian pelayanan sebaiknya selalu memantau kepuasan yang dirasakan oleh nasabah perbankan untuk mencapai loyalitas dari para nasabah.

Dalam memberikan pelayanan, setidaknya bank harus memenuhi 5 kriteria kualitas pelayanan yang sering disebut RATER sehingga dapat menciptakan nasabah yang loyal, yaitu reabillity (kehandalan), assurance (jaminan), tangible (bukti fisik), empathy (komunikasi), dan responsiveness (cepat tanggap), Tjiptono (2006:69). Kehandalan dapat dilihat dari kemampuan untuk memberikan jasa secara akurat sesuai yang dijanjikan, jaminan dapat dilihat dari pengetahuan dan kemampuan karyawan untuk melayani dengan rasa percaya diri, bukti fisik dapat dilihat dari fasilitas yang kasat mata yang dapat dinikmati langsung oleh nasabah, komunikasi yaitu karyawan harus memberikan perhatian secara individu kepada nasabah dan mengerti kebutuhan nasabah, sedangkan cepat tanggap kemampuan karyawan untuk membantu nasabah menyediakan jasa dengan cepat sesuai dengan yang diinginkan oleh nasabah. Salah satu cara menciptakan pelayanan yang berkualitas adalah bank dapat membedakan dirinya sendiri dengan cara konsisten menyampaikan mutu lebih tinggi ketimbang pesaingnya, pihak bank melakukan interaksi dengan nasabah yang disertai umpan balik sebagai kontrol dan ukuran keberhasilan.

Tabel 1.

Perkembangan Tabungan Bank Sinarmas Kantor Kas Kel. Duri Pulo, Gambir, Jakarta Pusat Periode 2011 sampai 2016

\begin{tabular}{crrrr}
\hline Tahun & $\begin{array}{c}\text { Jumlah } \\
\text { Nasabah }\end{array}$ & $\begin{array}{c}\text { Perkembangan } \\
\text { Jumlah } \\
\text { Nasabah (\%) }\end{array}$ & $\begin{array}{c}\text { Jumlah Nominal } \\
\text { (Rp) }\end{array}$ & $\begin{array}{c}\text { Perkembangan } \\
\text { Jumlah Nominal } \\
(\%)\end{array}$ \\
\hline 2011 & 711 & 3,48 & $3.468 .187 .983,64$ & 5,33 \\
2012 & 1.034 & 5,73 & $5.221 .003 .811,45$ & 8,67 \\
2013 & 1.127 & 2,33 & 5.718 .995 .440 .31 & 3,21 \\
2014 & 1.155 & 1,25 & $5.936 .330 .480,12$ & 2,44 \\
2015 & 1.236 & 2,98 & $7.008 .035 .150,92$ & 4,34 \\
2016 & 1.394 & 2,67 & $7.841 .756 .750,36$ & 2,96 \\
\hline Sumber : Data sekunder Bank Sinarmas, Persero, Tbk. KK Duri Pulo, Data Diolah
\end{tabular}

Berdasarkan dari tabel 1 di atas, dapat dijelaskan bahwa jumlah nasabah dan jumlah nominal pada tabungan pada tabungan Sinarmas selama 6 tahun terakhir yaitu tahun 2011 sampai dengan tahun 2016 mengalami peningkatan tertinggi pada tahun 2012 dimana jumlah nasabah tabungan Sinarmas sebanyak 1.034 orang dengan persentase sebesar 5,73\% dan jumlah nominal sebesar 5.221.003.811,45 dengan persentase 67\%. Namun, trend yang diperoleh berupa rata-rata perubahan yang relatif menurun dari tahun ke tahun. Penurunan paling drastis tampak pada tahun 2014 yaitu hanya tercapai 1,25\% perkembangan jumlah nasabahnya. Selanjutnya pada tahun yang sama perkembangan jumlah nominal hanya tercapai $2,44 \%$.

Pada studi pendahuluan, beberapa fenomena agar dijadikan sebagai pembenahan bagi Bank Sinarmas KK Duri Pulo yaitu adanya jumlah keluhan dari nasabah dari tahun ke tahun. Adapun informasi jumlah keluhan nasabah dapat dilihat pada tabel berikut ini: 
Tabel 2.

Jumlah Keluhan Nasabah Bank Sinarmas Kantor Kas Kel. Duri Pulo, Gambir, Jakarta Pusat

\begin{tabular}{ccc}
\hline No. & Tahun & Jumlah Keluhan \\
\hline 1 & 2011 & 116 \\
2 & 2012 & 152 \\
3 & 2013 & 124 \\
4 & 2014 & 193 \\
5 & 2015 & 166 \\
6 & 2016 & 201 \\
7 & 2017 & 215 \\
\hline Sumber : Data sekunder Bank Sinarmas, Persero, Tbk. KK Duri Pulo, Data Diolah
\end{tabular}

Berdasarkan data tabel 2, dapat diketahui bahwa selisih keluhan nasabah pada tahun 2014 mengalami kenaikan yang paling besar. Kenaikan pada tahun tersebut dipengaruhi oleh banyak faktor tergantung jenis keluhannya. Hal tersebut mengindikasikan adanya penurunan kualitas pelayanan yang disampaikan oleh banyak pihak penyedia jasa, sehingga berdampak pada penurunan keputusan nasabah yang tinggi.

Salah satu faktor yang menjadi penyebab terjadinya hal tersebut yakni adanya persaingan yang ketat dan banyaknya alternatif pilihan jasa perbankan sehingga nasabah semakin selektif. Upaya untuk mengantisipasi keadaan tersebut adalah bagaimana menentukan biaya yang fair value dan kualitas layanan yang dapat menciptakan kepuasan nasabah sehingga berimplikasi pada loyalitas nasabah.

Tujuan dari penelitian ini adalah untuk mengetahui dan menganalisis pengaruh harga terhadap kepuasan nasabah, pengaruh harga terhadap loyalitas nasabah Bank Sinarmas KK Duri Pulo Gambir Jakarta Pusat, pengaruh kualitas layanan terhadap kepuasan nasabah, dan pengaruh kualitas layanan terhadap loyalitas nasabah Bank Sinarmas KK Duri Pulo Gambir Jakarta Pusat, serta pengaruh kepuasan nasabah terhadap loyalitas nasabah Bank Sinarmas KK Duri Pulo Gambir Jakarta Pusat.

Manfaat yang diharapkan dari penelitian ini yaitu, memberikan pengaruh yang berdaya guna secara teoritis, metodologis dan empiris bagi kepentingan akademis dalam bidang manajemen pemasaran, dapat dijadikan suatu pola dan strategi dalam meningkatkan loyalitas pelanggan/nasabah. Bagi pengembangan ilmu pengetahuan, sebagai sarana pengembangan ilmu pengetahuan manajemen pemasaran khususnya tentang pentingnya penentuan harga, kualitas layanan, dan kepuasan nasabah dalam meningkatkan loyalitas nasabah. Bagi Stakeholder, sebagai masukan kepada investor dan perusahaan jasa keuangan, perbankan dalam mengambil kebijakan terutama mengenai permasalah ini. Tulisan ini dijadikan salah satu sumber bacaan yang dapat dipertimbangkan dalam pemecahan masalah yang relevan.

Selanjutnya bagi peneliti lebih lanjut, sebagai tambahan referensi bagi masyarakat ilmiah yang berminat melakukan penelitian pada bidang yang sama khususnya mengenai masalah pemasaran.

Menurut pemahaman secara umum, Loyalitas pelanggan adalah komitmen yang kuat dari pelanggan untuk berlangganan kembali atau melakukan pembelian ulang produk atau jasa yang disukai secara konsisten di masa yang akan datang, meskipun pengaruh situasi dan usaha - usaha pemasaran mempunyai potensi untuk menimbulkan perilaku untuk berpindah. Pelanggan yang loyal karena puas dan ingin meneruskan hubungan pembelian merupakan ukuran kedekatan pelanggan pada sebuah produk dan merek.

Pelanggan yang dianggap loyal akan berlangganan atau melakukan pembelian ulang selama jangka waktu tertentu. Pelanggan yang loyal sangat berarti bagi badan usaha karena biaya untuk mendapatkan pelanggan baru lebih mahal daripada memelihara pelanggan lama (Peter dan Olson, 2010). 
Selanjutnya Tjiptono dan Chandra (2012) menyatakan bahwa selama ini loyalitas pelanggan kerap kali dikaitkan dengan perilaku pembelian ulang. Keduanya memang berhubungan, namun sesungguhnya berbeda. Dalam konteks merek, misalnya loyalitas mencerminkan komitmen psikologis terhadap merek tertentu, sedangkan perilaku pembelian ulang semata - mata menyangkut pembelian merek tertentu yang sama secara berulangkali (bisa dikarenakan memang karena satu - satunya merek yang tersedia, merek yang termurah dan

Berdasarkan beberapa pendapat di atas, dapat disimpulkan bahwa loyalitas nasabah/pelanggan adalah kesetiaan nasabah untuk komitmen pada bank tempat mereka menyimpan harta kekayaan dan atau melakukan pinjaman berupa produk-produk saya ditawarkan oleh bank tersebut.

Menurut Kotler (2007:177) kepuasan pelanggan adalah perasaan senang atau kecewa seseorang yang muncul setelah membandingkan antara persepsi/kesannya terhadap kinerja (atau hasil) suatu produk dan harapan-harapanya. Sedangkan menurut Rangkuti (2004:56) menjelaskan bahwa yang dimaksud dengan kepuasan konsumen yaitu perbedaan antara tingkat kepentingan dan kinerja atau hasil yang dirasakan.

Selanjutnya Oliver (dalam Peter dan Olson, 1996) menyatakan bahwa kepuasan pelanggan adalah rangkuman kondisi psikologis yang dihasilkan ketika emosi yang mengelilingi harapan tidak cocok dan dilipatgandakan oleh perasaan-perasaan yang terbentuk mengenai pengalaman pengkonsumsian. Westbrook \& Reilly (dalam Tjiptono, 2007) mengemukakan bahwa kepuasan konsumen merupakan respon emosional terhadap pengalaman yang berkaitan dengan produk atau jasa yang dibeli.

Dari beberapa pendapat di atas, dapat disimpulkan bahwa kepuasan merupakan fungsi dari persepsi/kesan atau kinerja dan harapan. Jika kinerja berada dibawah harapan, pelanggan tidak puas. Jika kinerja memenuhi harapan, pelanggan puas. Jika kinerja melebihi harapan, pelanggan amat puas atau senang.

Menurut Lewis \& Booms (dalam Tjiptono, 2013:157) mendefinisikan kualitas pelayanan secara sederhana, yaitu ukuran seberapa bagus tingkat layanan yang diberikan mampu sesuai dengan ekspektasi pelanggan. Artinya kualitas pelayanan ditentukan oleh kemampuan perusahaan atau lembaga tertentu untuk memenuhi kebutuhan yang sesuai dengan apa yang diharapkan atau diinginkan berdasarkan kebutuhan pelanggan/pengunjung.

Kualitas pelayanan memberikan suatu dorongan kepada pelanggan atau dalam hal ini pengunjung untuk menjalin ikatan hubungan yang kuat dengan lembaga atau instansi pemberi pelayanan jasa. Ikatan hubungan yang baik ini akan memungkinkan lembaga pelayanan jasa untuk memahami dengan seksama harapan pelanggan/pengunjung serta kebutuhan mereka. Dengan demikian penyedia layanan jasa dapat meningkatkan kepuasan pengunjung dengan memaksimalkan pengalaman pengunjung yang menyenangkan dan meminimumkan pengalaman pengunjung yang kurang menyenangkan. Apabila layanan yang diterima atau dirasakan sesuai dengan harapan pelanggan, maka kualitas yang diterima atau dirasakan sesuai dengan harapan pelanggan, maka kualitas layanan dipersepsikan sebagai kualitas ideal, tetapi sebaliknya jika layanan yang diterima atau dirasakan lebih rendah dari yang diharapkan maka kualitas layanan dipersepsikan rendah.

Harga merupakan faktor utama dalam penentuan posisi dan harus diputuskan sesuai dengan pasar sasaran, bauran ragam produk, dan pelayanan, serta persaingan (Phlip Kotler dan Amstrong, 2008).

Menurut (Tjiptono, 2013), Harga memiliki dua peranan utama dalam proses pengambilan keputusan para pembeli yaitu peranan alokasi dan peranan informasi. Harga (price) adalah jumlah uang yang dibebankan atau dikenakan atas sebuah produk atau produk. Dengan kata lain harga merupakan sebuah nilai yang harus ditukarkan dengan produk yang dikehendaki konsumen. Harga merupakan satu - satunya elemen yang menghasilkan pendapatan sedangkan elemen lain menimbulkan biaya. Harga merupakan salahsatu elemen yang paling flexibel, harga dapat diubah dengan cepat. Namun ada beberapa perusahaaan yang tidak menangani penetapan harga yang terlalu berorientasi biaya, harga kurang sering divariasi untuk mengambil 
keuntungan dari perubahan pasar, harga ditetapkan secara independen dan bukannya sebagi unsur instrinsik dari strategi penentuan posisi pasar, serta harga kurang cukup bervariasi untuk berbagai macam poduk, segmen pasar, dan saat pembelian (Phlip Kotler dan Keller, 2012).

\section{METODE}

Berdasarkan kepada permasalahan yang akan diteliti, maka penelitian ini tergolong pada jenis penelitian deskriptif dan asosiatif. Melihat jumlah populasi yang cukup besar, maka pengambilan sampel dilakukan dengan teknik random sampling, dimana sampel diambil secara acak. Teknik pengumpulan data dalam penelitian ini menggunakan metode angket dan dokumentasi. Teknik analisis data dalam penelitian ini yaitu analisis deskriptif dan analisis jalur.

\section{HASIL DAN PEMBAHASAN}

\section{Analisis Deskriptif}

Distribusi frekuensi loyalitas nasabah dengan indikator kesetiaan terhadap pembelian produk perbankan dapat diketahui rerata skor 4,00 dengan tingkat ketercapaian responden yaitu 80,00\%. Angka ini berada pada rentang 71\% - 85\% dapat dikatakan baik. Artinya bahwa nasabah memiliki komitmen kuat untuk tetap menabung dan atau membeli produk jasa bank Sinarmas.

Kemudian pada indikator Ketahanan terhadap pengaruh negatif skor rata-rata 3,62 dengan tingkat ketercapaian responden sebesar 72,348\%. Angka ini berada pada rentang $71 \%-85 \%$, berarti rata-rata nasabah tetap percaya dengan bank Sinarmas. Begitu juga untuk indikator mereferensikan secara total eksistensi bank ,tingkat ketercapaian responden sebesar $85,74 \%$. Angka ini berada pada rentang 86\% - 100\% berarti nasabah Sinarmas intens merekomendasikan teman, saudara atau orang lain untuk membeli produk perbankan di bank Sinarmas. Tingkat ketercapaian responden untuk variabel loyalitas nasabah adalah $79.15 \%$, Hal ini bermakna bahwa secara rata-rata loyalitas nasabah bank Sinarmas KK Duri Pulo berkategori baik.

Tabel 1. Distribusi Frekuensi Loyalitas Nasabah

\begin{tabular}{|c|c|c|c|c|c|c|c|c|c|c|c|c|c|c|}
\hline \multirow{2}{*}{ No. } & \multirow{2}{*}{ Indikator } & \multicolumn{2}{|c|}{ Selalu } & \multicolumn{2}{|c|}{ Sering } & \multicolumn{2}{|c|}{$\begin{array}{l}\text { Kadang- } \\
\text { Kadang }\end{array}$} & \multicolumn{2}{|c|}{ Jarang } & \multicolumn{2}{|c|}{$\begin{array}{l}\text { Tidak } \\
\text { Pernah }\end{array}$} & \multirow{2}{*}{$\begin{array}{c}\text { Rerat } \\
\text { a } \\
(m e a \\
n)\end{array}$} & \multirow{2}{*}{$\begin{array}{c}\mathrm{TC} \\
\mathrm{R} \\
(\%)\end{array}$} & \multirow[t]{2}{*}{ Ket. } \\
\hline & & $F i$ & $\%$ & $F i$ & $\%$ & $F i$ & $\%$ & $F i$ & $\%$ & $F i$ & $\%$ & & & \\
\hline 1 & $\begin{array}{l}\text { Kesetiaan } \\
\text { terhadap } \\
\text { pembelian } \\
\text { produk }\end{array}$ & 29 & $\begin{array}{l}30 . \\
85\end{array}$ & 44 & $\begin{array}{l}46 . \\
81\end{array}$ & $\begin{array}{l}1 \\
5\end{array}$ & $\begin{array}{l}15 . \\
96\end{array}$ & 4 & 4.26 & 2 & $\begin{array}{l}2 . \\
13\end{array}$ & 4.00 & $\begin{array}{c}80.0 \\
0\end{array}$ & Baik \\
\hline 2 & $\begin{array}{l}\text { Ketahanan } \\
\text { terhadap } \\
\text { pengaruh } \\
\text { negatif }\end{array}$ & 20 & $\begin{array}{l}21 . \\
28\end{array}$ & 36 & $\begin{array}{l}38 . \\
30\end{array}$ & $\begin{array}{l}2 \\
3\end{array}$ & $\begin{array}{l}24 . \\
47\end{array}$ & 12 & $\begin{array}{c}12.7 \\
7\end{array}$ & 3 & $\begin{array}{l}3 . \\
19\end{array}$ & 3.62 & $\begin{array}{c}72.3 \\
4\end{array}$ & Baik \\
\hline 3 & $\begin{array}{l}\text { Mereferens } \\
\text { ikan secara } \\
\text { total } \\
\text { eksistensi } \\
\text { bank }\end{array}$ & 42 & $\begin{array}{l}44 . \\
68\end{array}$ & 39 & $\begin{array}{l}41 . \\
49\end{array}$ & $\begin{array}{l}1 \\
1\end{array}$ & $\begin{array}{l}11 . \\
70\end{array}$ & 2 & 2.13 & 0 & $\begin{array}{l}0 . \\
00\end{array}$ & 4.29 & $\begin{array}{c}85.7 \\
4\end{array}$ & $\begin{array}{l}\text { Sanga } \\
\text { t Baik }\end{array}$ \\
\hline $\operatorname{Re}$ & ta Variabel & 30 & $\begin{array}{l}31 . \\
91\end{array}$ & 40 & $\begin{array}{l}42 . \\
55\end{array}$ & $\begin{array}{l}1 \\
6\end{array}$ & $\begin{array}{l}17 . \\
02\end{array}$ & 6 & 6.38 & 2 & $\begin{array}{l}2 . \\
13\end{array}$ & 3.96 & $\begin{array}{c}79.1 \\
5 \\
\end{array}$ & Baik \\
\hline
\end{tabular}

Sumber : Pengolahan Data Primer Tahun 2017 
Pada tabel 2, yaitu ringkasan tabel distribusi frekuensi kepuasan nasabah. Terlihat pada variabel kepuasan nasabah dengan indikator Kepuasan keseluruhan dengan pelayanan dapat diketahui skor rata-rata sebesar 4,19 tingkat ketercapaian responden yaitu 83,83\%. Angka ini berada pada rentang $71 \%$ - 85\% dapat diartikan bahwa Kepuasan keseluruhan dengan pelayanan dikategorikan baik.

Sedangkan pada indikator Kepuasan keseluruhan dengan produk bank skor rata-rata sebesar 3,95 dengan tingkat ketercapaian responden sebesar 78,94\%. Angka ini berada pada rentang $71 \%-85 \%$, dikategorikan baik. Maknanya bahwa rata-rata nasabah merasa puas dengan produk bank.

Tingkat ketercapaian responden untuk variabel kepuasan nasabah bank Sinarmas KK Duri Pulo adalah $81,06 \%$, hal ini bermakna bahwa kepuasan nasabah dikatakan baik, karena pada rentang $71 \%-85 \%$.

Tabel 2. Distribusi Frekuensi Kepuasan Nasabah

\begin{tabular}{|c|c|c|c|c|c|c|c|c|c|c|c|c|c|c|}
\hline \multirow[t]{2}{*}{ No. } & \multirow[t]{2}{*}{ Indikator } & \multicolumn{2}{|c|}{$\begin{array}{c}\text { Sangat } \\
\text { Puas }\end{array}$} & \multicolumn{2}{|c|}{ Puas } & \multicolumn{2}{|c|}{$\begin{array}{c}\text { Biasa } \\
\text { Saja }\end{array}$} & \multicolumn{3}{|c|}{ Kurang Puas } & \multirow{2}{*}{$\begin{array}{c}\text { Tidak } \\
\text { Puas } \\
\% \\
\end{array}$} & \multirow{2}{*}{$\begin{array}{l}\text { Rerata } \\
\text { (mean) }\end{array}$} & \multirow{2}{*}{$\frac{\text { TCR }}{(\%)}$} & \multirow[t]{2}{*}{ Ket. } \\
\hline & & $F i$ & $\%$ & $F i$ & $\%$ & $F i$ & $\%$ & $F i$ & $\%$ & $F i$ & & & & \\
\hline 1 & $\begin{array}{l}\text { Kepuasan } \\
\text { keseluruhan } \\
\text { dengan } \\
\text { pelayanan }\end{array}$ & 37 & $\begin{array}{l}39 \\
.3 \\
6\end{array}$ & 38 & $\begin{array}{c}40.4 \\
3\end{array}$ & 19 & $\begin{array}{c}21 \\
.2 \\
1\end{array}$ & 0 & $\begin{array}{c}0 . \\
00\end{array}$ & 0 & 0.00 & 4.19 & $\begin{array}{c}83.8 \\
3\end{array}$ & Baik \\
\hline 2 & $\begin{array}{l}\text { Kepuasan } \\
\text { keseluruhan } \\
\text { dengan produk } \\
\text { bank }\end{array}$ & 22 & $\begin{array}{c}23 \\
.4 \\
0\end{array}$ & 48 & $\begin{array}{c}51.0 \\
6\end{array}$ & 21 & $\begin{array}{l}22 \\
.3 \\
4\end{array}$ & 3 & $\begin{array}{l}3 . \\
19\end{array}$ & 0 & 0.00 & 3.95 & $\begin{array}{c}78.9 \\
4\end{array}$ & Baik \\
\hline & ata Variabel & 29 & $\begin{array}{l}30 \\
.8 \\
5\end{array}$ & 43 & $\begin{array}{c}45.7 \\
4\end{array}$ & 20 & $\begin{array}{l}21 \\
.2 \\
8\end{array}$ & 2 & $\begin{array}{l}2 . \\
13\end{array}$ & 0 & 0.00 & 4.05 & $\begin{array}{c}81.0 \\
6\end{array}$ & Baik \\
\hline
\end{tabular}

Sumber : Pengolahan Data Primer Tahun 2017

Tabel 3. Distribusi Frekuensi Kualitas Layanan

\begin{tabular}{|c|c|c|c|c|c|c|c|c|c|c|c|c|c|c|}
\hline \multirow{3}{*}{ No. } & \multirow{3}{*}{ Indikator } & \multirow{2}{*}{\multicolumn{2}{|c|}{$\begin{array}{l}\text { Sangat } \\
\text { Setuju }\end{array}$}} & \multirow{2}{*}{\multicolumn{2}{|c|}{ Setuju }} & \multirow{2}{*}{\multicolumn{2}{|c|}{ Biasa Saja }} & \multirow{2}{*}{\multicolumn{3}{|c|}{ Kurang Setuju }} & \multirow{3}{*}{$\begin{array}{c}\text { Tida } \\
\mathrm{k} \\
\text { Setu } \\
\text { ju }\end{array}$} & \multirow{3}{*}{$\begin{array}{c}\text { Rerata } \\
\\
\begin{array}{c}\text { mean } \\
)\end{array}\end{array}$} & \multirow{3}{*}{$\begin{array}{r}\text { TCR } \\
(\%)\end{array}$} & \multirow{3}{*}{ Ket. } \\
\hline & & & & & & & & & & & & & & \\
\hline & & $F i$ & $\%$ & $F i$ & $\%$ & $F i$ & $\%$ & $F i$ & $\%$ & $\mathrm{Fi}$ & & & & \\
\hline 1 & Tangible & 45 & $\begin{array}{c}47.8 \\
7\end{array}$ & 33 & $\begin{array}{c}35 \\
.1 \\
1 \\
\end{array}$ & 10 & $\begin{array}{c}10.6 \\
4\end{array}$ & 6 & 6.38 & 0 & 0.00 & 4.24 & $\begin{array}{c}84.8 \\
9\end{array}$ & Baik \\
\hline 2 & Responsivitas & 35 & $\begin{array}{c}37.2 \\
3\end{array}$ & 44 & $\begin{array}{c}46 \\
.8 \\
1\end{array}$ & 11 & $\begin{array}{c}11.7 \\
0\end{array}$ & 4 & 4.26 & 0 & 0.00 & 4.17 & $\begin{array}{c}83.4 \\
0\end{array}$ & Baik \\
\hline 3 & $\begin{array}{l}\text { Assurancelad } \\
\text { anya jaminan }\end{array}$ & 52 & $\begin{array}{c}55.3 \\
2\end{array}$ & 29 & $\begin{array}{c}30 \\
.8 \\
5 \\
\end{array}$ & 13 & $\begin{array}{c}13.8 \\
3\end{array}$ & 0 & 0.00 & 0 & 0.00 & 4.41 & $\begin{array}{c}88.3 \\
0\end{array}$ & $\begin{array}{c}\text { Sangat } \\
\text { Baik }\end{array}$ \\
\hline 4 & Empati & 29 & $\begin{array}{c}30.8 \\
5\end{array}$ & 46 & $\begin{array}{c}48 \\
.9 \\
4 \\
\end{array}$ & 17 & $\begin{array}{c}18.0 \\
9\end{array}$ & 0 & 0.00 & 2 & 2.13 & 4.06 & $\begin{array}{c}81.2 \\
8\end{array}$ & Baik \\
\hline \multicolumn{2}{|c|}{ Rerata Variabel } & 41 & $\begin{array}{c}43.6 \\
2\end{array}$ & 38 & $\begin{array}{c}40 \\
.4 \\
3\end{array}$ & 13 & $\begin{array}{c}13.8 \\
3\end{array}$ & 2 & 2.13 & 0 & 0.00 & 4.26 & $\begin{array}{c}85.1 \\
1\end{array}$ & Baik \\
\hline
\end{tabular}

Sumber : Pengolahan Data Primer Tahun 2017

Dari hasil olahan data, pada tabel 3 di atas, dapat dilihat bahwa pada indikator tangible dapat diketahui skor rata-rata 4,24 dengan tingkat ketercapaian responden yaitu 84,89\%. Angka ini berada pada rentang $71 \%-85 \%$, artinya bukti fisik yang dimiliki oleh bank, seperti gedung, 
perlengkapan kantor, daya tarik karyawan, sarana komunikasi dan sarana fisik lainnya berkategori baik.

Kemudian pada indikator Responsivitas dapat diketahui skor rerata yaitu 4,17. Tingkat ketercapaian responden sebesar $83,40 \%$. Angka ini berada pada rentang $71 \%-85 \%$ yang berarti bahwa pada umumnya keinginan dan kemauan karyawan bank dalam memberikan pelayanan kepada nasabah baik, tanggap. Selanjutnya pada indikator Assurance/adanya jaminan dapat diketahui skor rerata sebesar 4,41 Tingkat ketercapaian responden sebesar 88,30\%. Angka ini berada pada rentang $86 \%$ - $100 \%$, Artinya bahwa karyawan memiliki pengetahuan, kompetensi, kesopanan dan sifat atau perilaku yang dapat dipercaya. Pada indikator empati skor rerata sebesar 4,06 Tingkat ketercapaian responden sebesar 81,28\%. Artinya bahwa karyawan mampu memberikan kemudahan serta menjalin hubungan nasabah secara efektif.

Tingkat ketercapaian responden untuk variabel kualitas layanan, dapat diketahui rerata variabelnya yaitu sebesar $85,11 \%$. Angka ini berada pada rentang $71 \%-85 \%$ yang berarti kualitas layanan pada kategori baik.

Tabel 4. Distribusi Frekuensi Harga

\begin{tabular}{|c|c|c|c|c|c|c|c|c|c|c|c|c|c|c|}
\hline \multirow{2}{*}{ No. } & \multirow{2}{*}{ Indikator } & \multicolumn{2}{|c|}{ Selalu } & \multicolumn{2}{|c|}{ Sering } & \multicolumn{2}{|c|}{$\begin{array}{l}\text { Kadang- } \\
\text { Kadang }\end{array}$} & \multicolumn{2}{|c|}{ Jarang } & \multicolumn{2}{|c|}{$\begin{array}{c}\text { Tidak } \\
\text { Pernah }\end{array}$} & \multirow{2}{*}{$\begin{array}{l}\text { Rerata } \\
\text { (mean) }\end{array}$} & \multirow{2}{*}{$\begin{array}{c}\text { TCR } \\
(\%) \\
\end{array}$} & \multirow[t]{2}{*}{ Ket. } \\
\hline & & $F i$ & $\%$ & $F i$ & $\%$ & $F i$ & $\%$ & $F i$ & $\%$ & $F i$ & $\%$ & & & \\
\hline 1 & $\begin{array}{l}\text { harga } \\
\text { penetrasi }\end{array}$ & 30 & 31.91 & 47 & 50.00 & 16 & $\begin{array}{c}17.0 \\
2\end{array}$ & 1 & 1.06 & 0 & $\begin{array}{l}0 . \\
00\end{array}$ & 4.13 & 82.55 & Baik \\
\hline 2 & $\begin{array}{l}\text { harga } \\
\text { paritas }\end{array}$ & 31 & 32.98 & 51 & 54.26 & 12 & $\begin{array}{c}12.7 \\
7 \\
\end{array}$ & 0 & 0.00 & 0 & $\begin{array}{l}0 . \\
00 \\
\end{array}$ & 4.20 & 84.04 & Baik \\
\hline 3 & $\begin{array}{l}\text { harga } \\
\text { premium }\end{array}$ & 48 & 51.06 & 34 & 36.17 & 11 & $\begin{array}{c}11.7 \\
0\end{array}$ & 1 & 1.06 & 0 & $\begin{array}{l}0 . \\
00\end{array}$ & 4.37 & 87.45 & $\begin{array}{c}\text { San } \\
\text { gat } \\
\text { Baik }\end{array}$ \\
\hline Rer & ta Variabel & 37 & 39.36 & 44 & 46.81 & 13 & $\begin{array}{c}13.8 \\
3\end{array}$ & 0 & 0.00 & 0 & $\begin{array}{c}0 . \\
00\end{array}$ & 4.26 & 85.11 & Baik \\
\hline
\end{tabular}

Pada tabel 4, distribusi frekuensi harga. Terlihat pada indikator harga penetrasi diketahui skor rata-rata sebesar 4,13 tingkat ketercapaian responden sebesar 82,55\%. Angka ini berada pada rentang $71 \%-85 \%$ dapat diartikan bahwa harga penetrasi baik. Selanjutnya pada indikator harga paritas dapat diketahui skor rerata sebesar 4,20 dengan tingkat ketercapaian responden untuk indikator harga paritas sebesar 84,04\%. Dapat diartikan bahwa bank Sinarmas menetapkan harga dengan tingkat yang sama atau mendekati tingkat harga pesaing.

Selanjutnya, pada indikator harga premium tingkat ketercapaian responden sebesar $87,45 \%$. Angka ini berada pada rentang $86 \%-100 \%$, artinya pada kategori sangat baik. Harga dapat diketahui tingkat capaian responden sebesar 85,11 \%, hal ini bermakna bahwa bank Sinarmas dalam menetapkan harga dapat dikatakan sudah baik.

\section{Analisis Induktif}

Uji Hipotesis

Berdasarkan pengujian hipotesis, dapat dilihat pengaruh langsung dan tidak langsung variabel independen melalui variabel intervening terhadap variabel dependen sebagai berikut:

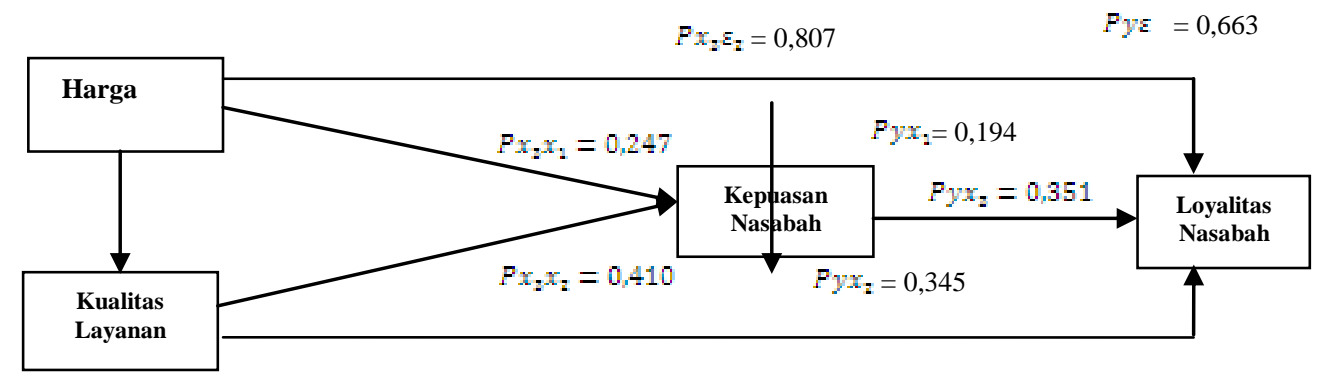




\section{Gambar 1. Pengaruh Langsung dan Tidak Langsung antara Variabel Bebas terhadap Variabel Terikat}

Pada tabel berikut ini dapat dilihat secara jelas pengaruh langsung dan pengaruh tidak langsung antara variabel sebab dan variabel akibat:

Tabel 5. Tabel Pengaruh Langsung dan Pengaruh Tidak Langsung

\begin{tabular}{llccc}
\hline & \multicolumn{2}{c}{ Variabel } & \multicolumn{3}{c}{ Pengaruh } \\
\cline { 3 - 5 } No. & $\begin{array}{c}\text { Tindak } \\
\text { Langsung }\end{array}$ & Langsung & $\begin{array}{c}\text { Total } \\
(\%)\end{array}$ \\
\hline 1. & $\mathrm{X}_{1}$ terhadap Y & - & 0,0376 & 3,76 \\
2. & $\mathrm{X}_{1}$ terhadap Y melalui $\mathrm{X}_{3}$ & 0,0168 & - & 1,68 \\
3. & $\mathrm{X}_{2}$ terhadap Y & - & 0,1190 & 11,90 \\
4. & $\mathrm{X}_{2}$ terhadap Y melalui $\mathrm{X}_{3}$ & 0,0496 & - & 4,96 \\
5. & $\mathrm{X}_{3}$ terhadap Y & - & 0,1232 & 12,32 \\
6. & Pengaruh variabel lain & - & - & 65,38 \\
\hline \multicolumn{4}{c}{ Total Keseluruhan } \\
\hline
\end{tabular}

Sumber : Pengolahan Data Primer Tahun 2017

\section{1) Hipotesis Pertama}

Diperoleh t hitung $=2,360$ sedangkan $t$ tabel $=1,987$. Hal ini menunjukkan bahwa $t_{\text {hit }}>$ $t_{t a b}(2,360>1,987)$, maka dapat disimpulkan bahwa hipotesis $\mathrm{H}_{0}$ ditolak. Artinya harga berpengaruh signifikan terhadap kepuasan nasabah.

2) Hipotesis Kedua

Diperoleh thitung $=3,911$ sedangkan $\mathrm{t}$ tabel $=1,987$. Hal ini menunjukkan bahwa $t_{\text {hit }}>$ $t_{t a b}(3,911>1,987)$, maka dapat disimpulkan bahwa Hipotesis $\mathrm{H}_{0}$ ditolak. Artinya kualitas layanan berpengaruh signifikan terhadap kepuasan nasabah.

3) Hipotesis Ketiga

Diperoleh thitung $=2,181$ sedangkan $t$ tabel $=1,987$. Hal ini menunjukkan bahwa $t_{\text {hit }}>$ $t_{\text {tab }}(2,181>1,987)$, maka dapat disimpulkan bahwa hipotesis $\mathrm{H}_{0}$ ditolak. Artinya harga berpengaruh signifikan terhadap loyalitas nasabah.

4) Hipotesis Keempat

Diperoleh $\mathrm{t}$ hitung $=3,687$, sedangkan $\mathrm{t}$ tabel $=1,987$. Hal ini menunjukkan bahwa $t_{\text {hit }}$ $>t_{\text {tab }}(3,687>1,987)$, maka dapat disimpulkan bahwa hipotesis $\mathrm{H}_{0}$ ditolak. Artinya kualitas layanan berpengaruh signifikan terhadap loyalitas nasabah.

5) Hipotesis Kelima

Diperoleh t hitung $=4,052$, sedangkan $\mathrm{t}$ tabel $=1,987$. Hal ini menunjukkan bahwa $t_{\text {hit }}$ $>t_{\text {tab }}(4,052>1,987)$, maka dapat disimpulkan bahwa hipotesis $\mathrm{H}_{0}$ ditolak. Artinya kepuasan nasabah berpengaruh signifikan terhadap loyalitas nasabah.

Dari hasil penelitian diperoleh bahwa :

1. Pengaruh Harga terhadap Kepuasan Nasabah Bank Sinarmas KK Duri Pulo Gambir Jakarta Pusat

Berdasarkan pengujian hipotesis diperoleh bahwa harga berpengaruh positif signifikan terhadap kepuasan nasabah Bank Sinarmas, artinya ketika harga sesuai harapan nasabah maka semakin meningkat kepuasan nasabah. Sebaliknya, harga tidak sesuai, maka kepuasan nasabah cenderung akan semakin menurun karena nasabah merasa kurang cocok dengan harga yang ditentukan oleh pihak bank. 
Harga yang tinggi menyebabkan perusahaan dapat mengurangi tingkat kesalahan atau mengurangi pemborosan terhadap produk. Suatu produk yang memiliki kualitas adalah produk yang dapat memenuhi kebutuhan dan keinginan konsumen sehingga konsumen puas dan melakukan pembelian ulang. Jika harga yang telah dibeli memenuhi harapan yang di inginkan konsumen, hal ini akan menimbulkan kepuasan bagi konsumen.

\section{Pengaruh Kualitas Layanan terhadap Kepuasan Nasabah Bank Sinarmas KK Duri Pulo} Gambir Jakarta Pusat

Berdasarkan pengujian hipotesis diperoleh bahwa kualitas layanan berpengaruh positif signifikan terhadap kepuasan nasabah Bank Sinarmas KK Duri Pulo Gambir Jakarta Pusat. Artinya apabila kualitas layanan meningkat, maka akan meningkat pula kepuasan nasabah. Sebaliknya, apabila kualitas layanan menurun, maka kepuasan nasabah pun akan menurun.

Kualitas pelayanan sangat penting dalam mendapatkan kepuasan konsumen dan sangat berhubungan erat. Kualitas pelayanan berperan sebagai variabel pendahulu bagi terciptanya kepuasan konsumen (Dick dan Basu, 1994:100). Kualitas akan memberikan suatu dorongan kepada pelanggan untuk menjalin ikatan hubungan yang kuat dengan perusahaan. Dengan demikian perusahaan dapat meningkatkan kepuasan pelanggan dimana perusahaan memaksimalkan pengalaman pelanggan yang menyenangkan dan meminimumkan atau meniadakan pengalaman pelanggan yang kurang menyenangkan. Hasil penelitian yang dilakukan oleh Fadma Yulianti (2013), juga membuktikan kualitas pelayanan mempengaruhi kepuasan nasabah.

3. Pengaruh Harga terhadap Loyalitas Nasabah Bank Sinarmas KK Duri Pulo Gambir Jakarta Pusat

Berdasarkan pengujian hipotesis, diperoleh bahwa harga berpengaruh positif signifikan terhadap loyalitas nasabah. Dari hasil analisis dapat diketahui pengaruh langsung harga terhadap loyalitas nasabah lebih besar pengaruhnya yaitu sebesar 3,76\% dibanding pengaruh tidak langsung melalui kepuasan nasabah yaitu sebesar 1,68\%. Hal ini dikarenakan hasil analisis deskriptif menunjukkan harga lebih besar TCRnya yaitu $85,11 \%$. Sementara kepuasan nasabah yaitu $81,06 \%$. Oleh karena itu fungsi kepuasan kerja hanya sebagai moderating variable.

Dari paparan tersebut, dapat disimpulkan maknanya yaitu bahwa untuk meningkatkan loyalitas nasabah, bukan hanya harga saja yang perlu disesuaikan. Akan tetapi terlebih dahulu harus meningkatkan kepuasan nasabah. Baik pengaruh langsung atau tidak langsung harga terhadap loyalitas nasabah, hasil uji hipotesis menunjukkan terdapat pengaruh positif signifikan harga terhadap loyalitas nasabah Bank Sinarmas KK Duri Pulo Gambir Jakarta Pusat. Hal ini dapat diartikan bahwa penetapan harga yang sesuai dengan permintaan pasar, cenderung meningkatkan loyalitas nasabah. Sebaliknya jika penetapan harga tidak sesuai, maka akan mengakibatkan nasabah cenderung tidak loyal atau pindah ke bank lain. Hal ini karena nasabah kurang puas dengan kebijakan bank, sehingga otomatis loyalitas cenderung mengalami penurunan.

Suatu produk yang memiliki kualitas adalah produk yang dapat memenuhi kebutuhan dan keinginan sesuai harapan konsumen, bahkan dapat melebihi apa yang diharapkan oleh konsumen sehingga konsumen puas dan melakukan pembelian ulang. Jika harga yang telah dibeli memenuhi harapan yang di inginkan konsumen, hal ini akan menimbulkan kepuasan bagi konsumen. Dan membangun tingkat loyalitas pelanggan. Keputusan penentuan harga demikian penting dalam menemukan seberapa jauh sebuah layanan jasa dinilai oleh konsumen dan juga dalam proses membangun tingkat loyalitas konsumen (Lupiyoadi, 2009). Hasil penelitian yang dilakukan oleh Rifqy Purwo Adi (2013), juga membuktikan kewajaran harga mempengaruhi loyalitas melalui kepuasan konsumen. 
4. Pengaruh Kualitas Layanan terhadap Loyalitas Nasabah Bank Sinarmas KK Duri Pulo Gambir Jakarta Pusat

Berdasarkan pengujian hipotesis diperoleh bahwa kualitas layanan berpengaruh positif signifikan terhadap loyalitas nasabah . Dari hasil analisis dapat diketahui pengaruh langsung kualitas layanan terhadap loyalitas nasabah lebih besar pengaruhnya yaitu sebesar 11,90\% dibanding pengaruh tidak langsung melalui kepuasan kerja yaitu hanya 4,96\%. Hal ini dikarenakan hasil analisis deskriptif menunjukkan kualitas layanan lebih besar TCRnya yaitu $85,11 \%$. Sementara kepuasan nasabah hanya $81,06 \%$. Oleh karena itu fungsi kepuasan nasabah hanya sebagai moderating variable.

Dari paparan tersebut, dapat disimpulkan maknanya yaitu bahwa untuk meningkatkan loyalitas nasabah, bukan hanya kualitas layanan saja yang perlu ditingkatkan. Akan tetapi harus meningkatkan kepuasan nasabah.

Kualitas Produk sangat berhubungan dengan loyalitas pelanggan, jika barang dan jasa dibeli cocok dengan apa yang diharapkan oleh konsumen, maka akan terdapat kepuasan atau loyalitas dan sebaliknya. Menurut (Goestch dan Davis, 2011) kualitas produk merupakan suatu kondisi dinamis yang dihubungkan dengan barang dan jasa, manusia, proses dari lingkungan yang memenuhi atau melebihi harapan. Disamping faktor kualitas produk yang mempengaruhi loyalitas pelanggan, terdapat faktor lain yang turut mempengaruhi loyalitas pelanggan yaitu kepuasan. Menurut (Swashta, 2012) kepuasan merupakan suatu dorongan keinginan individu yang diarahkan pada tujuan untuk memperoleh kepuasan. Konsumen akan setia dan loyal pada suatu merek apabila konsumen mendapatkan kepuasan dari merek tersebut. Telah banyak penelitian terdahulu mengenai kepuasan sebagai variabel moderasi, diantaranya adalah penelitian (Dharmayanti, 2006) yang menyimpulkan bahwa service performance memiliki pengaruh langsung yang kuat terhadap loyalitas, dan service performance yang baik tidak selalu menghasilkan kepuasan. Tetapi hadirnya kepuasan sebagai moderating variable bukan sebagai intervening variable adalah tepat, karena telah terbukti bahwa kepuasan mampu memoderate pengaruh service performance terhadap kepuasan. Hasil penelitian ini diperkuat oleh jurnal Melysa Elisabeth Pongoh (2013), Irawan, Deni dan Edwan Japarianto (2013).

\section{Pengaruh Kepuasan Nasabah terhadap Loyalitas Nasabah Bank Sinarmas KK Duri Pulo} Gambir Jakarta Pusat

Berdasarkan pengujian hipotesis diperoleh bahwa kepuasan nasabah berpengaruh positif signifikan terhadap loyalitas nasabah Bank Sinarmas KK Duri Pulo Gambir Jakarta Pusat. Artinya apabila kepuasan nasabah meningkat, maka akan meningkatkan loyalitas nasabah. Sebaliknya, apabila nasabah tidak puas maka secara otomatis loyalitas nasabah cenderung akan menurun.

Kepuasan konsumen adalah suatu keadaan dimana keinginan, harapan dan kebutuhan konsumen dipenuhi. Suatu pelayanan dinilai memuaskan bila pelayanan tersebut dapat memenuhi kebutuhan dan harapan konsumen. Pengukuran kepuasan konsumen merupakan elemen penting dalam menyediakan pelayanan yang lebih baik, lebih efisien dan lebih efektif, apabila konsumen merasa tidak puas terhadap suatu pelayanan yang disediakan, maka pelayanan tersebut dapat dipastikan tidak efektif dan tidak efisien. Dengan adanya kepuasan konsumen maka akan dapat menciptakan keputusan pembelian. Sesuai dengan teori (Philip Kotler dan Keller, 2012) bahwa kepuasan atau ketidakpuasan konsumen akan mempengaruhi perilaku konsumen.

Hasil penelitian ini sejalan dengan penelitian dari Janita dan Kusumawati (2014) yang menunjukkan bahwa terdapat pengaruh yang positif dan signifikan kepuasan pelanggan terhadap loyalitas Pelanggan McDonald's MT. Haryono, Malang 


\section{SIMPULAN}

Berdasarkan hasil dan pembahasan tersebut maka dapat disimpulkan bahwa :

1. Harga berpengaruh positif signifikan terhadap kepuasan nasabah Bank Sinarmas KK Duri Pulo Gambir Jakarta Pusat. Artinya apabila harga yang telah ditetapkan oleh bank sesuai dengan nasabah, maka semakin meningkat kepuasan nasabah. Sebaliknya, harga tidak sesuai, maka kepuasan nasabah cenderung akan semakin menurun.

2. Kualitas layanan berpengaruh positif signifikan terhadap kepuasan nasabah Bank Sinarmas KK Duri Pulo Gambir Jakarta Pusat. Artinya apabila pelayanan ditingkatkan mutu/kualitasnya, maka akan meningkat pula kepuasan pada diri nasabah. Sebaliknya, apabila layanan menurun, maka kepuasan pun akan menurun. Harga berpengaruh positif signifikan terhadap loyalitas nasabah Bank Sinarmas KK Duri Pulo Gambir Jakarta Pusat, baik secara langsung maupun tidak langsung. Artinya bahwa harga yang telah ditetapkan oleh bank sesuai dengan kemauan, daya beli nasabah, maka cenderung akan meningkatkan loyalitas nasabah. Sebaliknya jika harga yang telah ditetapkan oleh bank tidak sesuai, maka akan mengakibatkan nasabah cenderung tidak loyal, berusaha untuk pindah atau mencari informasi untuk pindah ke bank lain.

3. Kualitas layanan berpengaruh positif signifikan terhadap loyalitas nasabah, baik secara langsung maupun tidak langsung. Artinya apabila kualitas layanan ditingkatkan lagi, maka loyalitas pada diri nasabah cenderung akan meningkat baik secara langsung maupun melalui peningkatan kepuasan.

4. Kepuasan nasabah berpengaruh positif signifikan terhadap loyalitas nasabah Bank Sinarmas KK Duri Pulo Gambir Jakarta Pusat. Artinya apabila kepuasan nasabah meningkat, maka akan meningkatkan loyalitas nasabah. Sebaliknya, apabila nasabah tidak puas maka secara otomatis loyalitas cenderung akan menurun.

\section{SARAN}

1. Kepada seluruh pegawai/karyawan Bank Sinarmas KK Duri Pulo Gambir Jakarta Pusat, agar ditingkatkan lagi sikap empati dan responsivitas/ daya tanggap terhadap nasabah guna meningkatkan mutu/kualitas layanan.

2. Kepada direktur bank/pimpinan Bank Sinarmas KK Duri Pulo Gambir Jakarta Pusat hendaknya perlu mempertimbangkan harga atas produk-produk jasa bank dengan daya beli masyarakat. Perlu penetapan harga penetrasi.

3. Kepada peneliti selanjutnya disarankan untuk meneliti faktor-faktor lain yang mempengaruhi loyalitas nasabah. Peneliti diharapkan melakukan penelitian dan pengembangan (R\&D).

\section{DAFTAR RUJUKAN}

Dharmayanti, Diah. (2006). Analisis Dampak Service Performance dan Kepuasan sebagai moderating variable terhadap Loyalitas Nasabah. Jurnal Manajemen Pemasaran. Vol 1 No.1 April 2006.

Dick, A. S. dan Basu, K. (1994). Customer Loyalty : Towards an Integrated Conceptual Framework. Journal of the Academy of Marketing Science. 99-113.

Fadma Yulianti. (2013). Pengaruh Kualitas Pelayanan Terhadap Kepuasan Nasabah Bank Panin Tbk KCP A. Yani Banjarmasin: Jurnal SPREAD, Vol. 3 No. 2. Oktober 2013.

Goetsch, David L. dan Davis, Stanley B. (2011). Pengantar manajemen Mutu. Edisi Bahasa Indonesia. Jakarta : PT Prenhalindo. 
Irawan, Deni dan Edwan Japarianto. (2013). Analisa Pengaruh Kualitas Produk Terhadap Loyalitas melalui Kepuasan Sebagai Variabel Intervening Pada Pelanggan Restoran POR KEE Surabaya, Jurnal Manajemen Pemasaran, Vol. 1, No. 2, (2013) 1-8.

Janita, Inka S. dan Andriani Kusumawati. (2014). Pengaruh Kualitas Produk dan Kualitas Pelayanan Terhadap Kepuasan Pelanggan Dalam Membentuk Loyalitas Pelanggan (Studi pada Pelanggan McDonald's MT. Haryono Malang), Jurnal administrasi Bisnis, Vol.15, No. 1. Oktober 2014.

Kotler, Philip dan Keller, Kevin Lane. (2012). Marketing Management. New Jersey : Pearson Prentice Hall Inc.

Kotler, Philip dan Armstrong, Garry. (2008). Prinsip-Prinsip Pemasaran, (Alih bahasa Bob Sabran) Jilid 1. Edisi keduabelas. Jakarta : Erlangga.

Kotler, Philip. (2007). Alih Bahasa: Benyamin Molan. Manajemen Pemasaran, edisi 12 Jilid 2. Jakarta: PT.INDEKS.

. (2007), Manajemen Pemasaran, Jilid I dan II, terjemahan Hendra Teguh Jakarta: PT. Prenhalindo.

Lupiyoadi. (2009). Manajemen Pemasaran Jasa. Jakarta : Salemba Empat.

Melysa Elisabeth Pongoh. (2013). Kualitas Pelayanan, Kualitas Produk Dan Harga Pengaruhnya Terhadap Loyalitas Pelanggan Kartu As Telkomsel Di Kota Manado: Management Analysis Journal EMBA 1(4): 86-94.

Peter, J. Paul dan Olson, Jerry C. (1996). Perilaku Konsumen dan Strategi Pemasaran. Gelora Aksara Pratama. Jakarta.

New York USA : Mc Graw Hill.

(2010). Consumer Behavior and Marketing Strategy 9th.

Rangkuti, Freddy. (2004). The Power of Brand. Jakarta : PT Gramedia Pustaka Utama. . (2008). Measuring Customer Satisfaction. Jakarta: PT. Gramedia Pustaka Utama.

Rifqy Purwo Adi. (2013). Pengaruh Kualitas Produk Dan Kewajaran Harga Terhadap Loyalitas Dengan Kepuasan Konsumen : Management Analysis Journal 2(1) (2013): 110115.

Tjiptono, Fandy dan Chandra, Gregorius. (2012). Pemasaran Strategik. Yogyakarta : Andi.

Tjiptono, Fandy. (2007). Service, Quality and Satisfaction. Yogyakarta: Andi

. (2006). Manajemen Pelayanan Jasa. Yogyakarta: Andi.

. (2013). Manajemen Pelayanan Jasa. Yogyakarta: Andi. 